\title{
Soybean Fungal Endophytes Alternaria and Diaporthe spp. are Differentially Impacted by Fungicide Application
}

\author{
Jean Carlson Batzer ${ }^{1}$ and Daren S. Mueller ${ }^{1,2, \dagger}$ \\ ${ }^{1}$ Plant Pathology and Microbiology Department, Iowa State University, Ames, IA \\ ${ }^{2}$ Integrated Pest Management Program, Iowa State University, Ames, IA
}

\begin{abstract}
In field trials in Iowa, we investigated the association of a fungicide applied at early pod set to the diversity and composition of foliar endophytic fungi in presenescent soybeans. The main purpose of our study was to determine whether fungicides affect the microbiome of soybean plants during the pod-fill reproductive stage. In a replicated experiment focused on the impact of a fungicide application including a quinone outside inhibitor (QoI) and a pyrazole-carboxamide spanning two growing seasons, healthy stems and leaves near the tops of soybean were sampled for endophytic fungi. The survey yielded 1,791 isolates belonging to 17 putative species, identified by morphology and sequence analysis of

were analyzed separately using a multivariate community analysis of isolate counts per plant. The $14.3 \%$ fluxapyroxad and $28.6 \%$ pyraclostrobin fungicide spray significantly increased the proportion of Diaporthe isolates over no-spray controls, whereas the inverse occurred for foliar Alternaria isolates. In addition, seed harvested from fields with shorter-season varieties and sprayed with fungicide showed higher percentages of Diaporthe isolates than fields with no fungicide spray. In conclusion, soybean farmers may want to consider that the application of a QoI fungicide in the absence of disease pressure might adversely impact seed quality.
\end{abstract} the ribosomal DNA internal transcribed spacer region. Taxa were grouped by genus into operational taxonomic units: Alternaria, Colletotrichum, and Diaporthe were the dominant genera isolated. Plant parts

Keywords: Fusarium, Glycine max, latent infection, maturity groups, microbial communities, molecular identification, Nigrospora, strobilurin

Fungal endophytes inhabit plants without causing visible disease symptoms. The designation "endophyte" refers only to the moment of detection, without regard to future interactions (Schulz and Boyle 2005). Endophytic fungi act as mutualists, as pathogens when the host is stressed, or as saprobes when the host dies (Redman et al. 2001; White et al. 2016). Redman et al. (2002) showed that an endophytic Curvularia sp. increased host tolerance of Dichanthelium lanuginosum (panic grass) to temperatures up to $65^{\circ} \mathrm{C}$, thereby improving host fitness. On the other hand, several fungal endophytes produce phytotoxins in culture (Borges and Pupo 2006; de Lima Fávaro et al. 2012; Gao et al. 2011; Suryanarayanan et al. 2012). Schulz and Boyle (2005) suggested that asymptomatic colonization is a momentary balance of antagonisms between host and endophyte, regardless of the life-history strategy of the fungal endophyte. Therefore, crop management strategies that alter the physiology of the plant host may modify its endophytic community.

Transmission of endophytes is a key factor for their classification (Rodriguez et al. 2009). Class I endophytes are obligately related to and systemic within their hosts. For example, the Epichloë and Balansia endophytes are transmitted through the embryos of their grass and morning glory hosts, respectively (Tadych et al. 2007; White et al. 2016). Nonclaviciptaceous endophytes (classes II to IV) are facultatively related to multiple hosts and are typically vectored on the surfaces of seeds, plant residue, and soil (White et al. 2016). The compositions of communities of nonclaviciptaceous endophytes are influenced by local environment and geography (Arnold 2007; U'Ren et al. 2012). The nonclaviciptaceous endophyte, Colletotrichum gloeosporioides, was found in eight different hosts in Thailand, but isolates differed in their ability to cause anthracnose among those hosts (Photita et al. 2005).

${ }^{\dagger}$ Corresponding author: D. S. Mueller; dsmuelle@iastate.edu

The author(s) declare no conflict of interest.

Accepted for publication 3 August 2019.

(C) 2020 The American Phytopathological Society
Surveys of the soybean (Glycine max L. Merrill) foliar fungal endophyte community have been conducted in Minnesota, Brazil, and Argentina (da Costa Stuart et al. 2018; de Souza Leite et al. 2013; Impullitti and Malvick 2013; Larran et al. 2002; Pimentel et al. 2006); these studies established repeatable culture-based methods for performing endophyte isolations. So-called "latent infection," defined as the association or colonization of tissues by pathogens for a prolonged period without visible symptoms, has long been detected in apparently healthy soybean plants (Sinclair 1991). Yet little is known about how these fungi affect their host as endophytes. There is some evidence that endophytes may reduce plant disease and enhance soybean growth. For instance, drenching with culture filtrate from the endophyte Cladosporium sphaerospermum increased soybean plant height (Hamayun et al. 2009). Salinity tolerance in soybean is promoted by a Penicillium endophyte (Khan et al. 2011).

Conversely, regardless of plant species, there is a scarcity of information on how agronomic practices or external factors shape the fungal or bacterial endophyte community. It has been reported that host genotype shapes the fungal endophyte community, as was noted for Phaseolus vulgaris (Parsa et al. 2016) as well as tree species (Hoffman and Arnold 2008; Oono et al. 2015). Insect damage did not impact the endophyte community of the white snakeroot plant (Ageratina altissima) (Christian et al. 2016). Pan and May (2009) showed that Ustilago maydis (corn smut) affected the assemblage of fungal endophyte communities in Zea mays. Fungicide applications on wheat showed a moderate but significant difference in the relative abundance and diversity of nontarget fungi (Karlsson et al. 2014). Kuklinsky-Sobral et al. (2005) found that two soybean cultivars (Foscarin and Cristalina) from fields treated with glyphosate herbicide differed in endophytic bacteria community from plants of the same cultivar without glyphosate treatment. Prior et al. (2017) showed that azoxystrobin had the greatest effect on endophytic community diversity on broad bean and common bean, compared with sulfur and copper, and lasted more than 5 weeks after application. da Costa Stuart et al. (2018) investigated the effect of cropping systems on soybean endophytes and found that conventional practices reduced foliar fungal endophyte diversity by one-third compared with organically grown soybeans. 
Midwestern U.S. soybean farmers have received conflicting advice regarding the advisability of applying quinone outside inhibitor (QoI) fungicides in the absence of disease to increase yields (Kandel et al. 2016; Swoboda and Pedersen 2009; Wise and Mueller 2011). QoI fungicides have been linked to delayed leaf senescence and prolonged photosynthetic activity of green tissue, which both impact yield (Balba 2007; Bradley and Sweets 2008). QoI fungicides include pyraclostrobin, azoxystrobin, and trifloxystrobin and belong to Fungicide Resistance Action Committee (FRAC) Code Group 11 fungicides also known as strobilurins (Mueller 2013).

The purpose of this study was to determine the effect of applying a fungicide spray containing a QoI on the soybean endophyte community. We used a culture-based approach to determine the diversity and incidence of fungal endophytes of leaves and stems. A followup investigation was also conducted to determine whether these fungal endophytes colonized the seed crop and whether internal seed colonization was impacted by fungicide spray.

\section{Materials and Methods}

Field study. This study was conducted using an ongoing fungicide trial, in which cultivars were provided by private industry in fields that were annually rotated between corn and soybean. Conventionally grown soybean fields were annually rotated with corn and were planted at Iowa State University research farms in $2015\left(\mathrm{~N} \mathrm{41}{ }^{\circ}\right.$

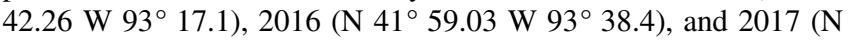
$42^{\circ} 23.8 \mathrm{~W} 93^{\circ} 38.1$ ) near Ames, Iowa, at a row spacing of $76 \mathrm{~cm}$ at a rate of 345,800 seeds/ha. A 0.5 -ha area contained three field strips with cultivars of differing maturity groups (MGs). Soybean MGs are based on the day length required to begin the reproductive process; each whole-number MG increase adds approximately 10 days to the onset of flowering (Edwards and Purcell 2005). Fungicide treatments (fungicide spray and no spray) were randomly assigned in four replicated four-row subplots $(6.1 \times 3 \mathrm{~m})$ per field (Table 1). The fields contained additional fungicide treatment plots not included in this study. At reproductive stage 3 (R3), when pods were beginning to fill (Fehr and Caviness 1977), designated plots were sprayed with a commercial fungicide $(292 \mathrm{ml} / \mathrm{ha})$ composed of $14.3 \%$ fluxapyroxad and $28.6 \%$ pyraclostrobin (FRAC codes 11 and 7) (Priaxor; BASF Corp., Research Triangle Park, NC) mixed with water. In mid-September 2015 and 2016, plant tissue samples for endophyte isolation were collected from the outer two rows of each four-row subplot, leaving the center rows for harvest. A total of 20 plants per fungicide treatment (fungicide spray and no spray) were collected and pooled across the four subplots (Table 2). Asymptomatic leaves at the fifth node from the top, were designated as "no spray" and "fungicide spray." The stem and leaf of that same plant was sampled. The reproductive stage of plants in each field was noted on the collection dates (Table 1) as described by Fehr and Caviness (1977). Briefly, reproductive stage 5 (R5) is "beginning seed" when seeds are $3 \mathrm{~mm}$ long in the pods located at the uppermost nodes of the main stem, R6 is "full seed" when a green seed fills the pod capacity at one of the four uppermost nodes on the main stem, and R7 is "beginning maturity" when one of the pods on the main stem reaches its mature color.

At harvest, grain weight and moisture content were collected for each subplot $(n=4)$ and grain weight was adjusted to $13 \%$ grain moisture (Table 1). Grain moisture measurements were determined as described by the American Society of Agricultural and Biological Engineers (2017). Paired comparisons of moisture and yield were made for fungicide spray and no-spray treatments for 2015, 2016, and 2017 ( 4 subplots $\times 3$ fields $\times 3$ years $\times 2$ fungicide treatments). Daily soil temperature and precipitation data were obtained from a weather station located within $3 \mathrm{~km}$ of the fields (Iowa Environmental Mesonet; http://mesonet.agron.iastate.edu/agclimate).

Foliar endophyte collection design. A total of six soybean fields were assessed in both 2015 and 2016. Twenty plant samples collected from each treatment (fungicide spray and no spray) were pooled across four subplots within treatment in each of the six fields. Thus, fields were treated as blocks $(n=6)$. Endophytes from stems and leaves were analyzed separately.

Seed collection design. In 2016 and 2017, three visibly healthy plants from outer rows of each of four subplots per field were flagged in mid-September for postharvest seed collection. Seed samples from each subplot were kept separate to obtain four replicates per field (six fields; $n=24$ ).

Leaf and stem endophyte collection. In 2015 and 2016, 20 plants ( $n=5$ per subplot) at R5 stage were collected and pooled across field treatment $(n=6)$. Twelve stems and 20 leaves per field in 2015 and 20 stems and 20 leaves per field in 2016 were sampled in the laboratory. A single leaflet and stem from each collected plant was plated

Table 1. Cultivars, key dates, and harvest data of fields used for testing the impact of a fungicide spray on fungal endophytes

\begin{tabular}{|c|c|c|c|c|c|c|c|c|c|c|c|}
\hline Year & Cultivar & Manufacturer & $\mathbf{M G}^{\mathbf{a}}$ & $\begin{array}{c}\text { Planting } \\
\text { date }\end{array}$ & $\begin{array}{l}\text { Fungicide } \\
\text { treatment }\end{array}$ & $\begin{array}{l}\text { Spray } \\
\text { date }^{c}\end{array}$ & $\begin{array}{c}\text { Foliar } \\
\text { collection date }\end{array}$ & $\begin{array}{c}\text { Reproductive } \\
\text { stage }^{d}\end{array}$ & $\begin{array}{c}\text { Harvest } \\
\text { date }\end{array}$ & $\begin{array}{l}\text { Yield } \\
\text { (t/ha) }\end{array}$ & $\begin{array}{c}\text { Seed } \\
\text { moisture }(\%)\end{array}$ \\
\hline \multirow[t]{6}{*}{2015} & AG2431 & Asgrow & 2.4 & 19 May & No & - & $15 \mathrm{Sep}$ & R6 & 8 Oct & 4.86 & 12.1 \\
\hline & & & & & Yes & 3 Aug & & & & 5.26 & 12.3 \\
\hline & 31RY45 & Pioneer & 3.1 & 19 May & No & - & $16 \mathrm{Sep}$ & R5 & 9 Oct & 4.68 & 15.5 \\
\hline & & & & & Yes & 3 Aug & & & & 4.54 & 16.3 \\
\hline & AG3334 & Asgrow & 3.3 & 19 May & No & - & $17 \mathrm{Sep}$ & $\mathrm{R} 5$ & 9 Oct & 4.57 & 15.9 \\
\hline & & & & & Yes & 3 Aug & & & & 4.44 & 16.4 \\
\hline \multirow[t]{6}{*}{2016} & AG2035 & Asgrow & 2.0 & 22 May & No & - & $10 \mathrm{Sep}$ & $\mathrm{R} 7$ & 17 Oct & 5.09 & 16.8 \\
\hline & & & & & Yes & $21 \mathrm{Jul}$ & & & & 5.20 & 16.8 \\
\hline & NKS24K2 & Syngenta & 2.4 & 22 May & No & - & $11 \mathrm{Sep}$ & R6 & 17 Oct & 4.51 & 11.8 \\
\hline & & & & & Yes & $21 \mathrm{Jul}$ & & & & 4.68 & 12.2 \\
\hline & 39RY43 & Dynagrow & 3.9 & 22 May & No & - & $12 \mathrm{Sep}$ & $\mathrm{R} 5$ & 24 Oct & 4.23 & 10.5 \\
\hline & & & & & Yes & $26 \mathrm{Jul}$ & & & & 4.28 & 10.5 \\
\hline \multirow[t]{6}{*}{2017} & AG2035 & Asgrow & 2.0 & 30 May & No & - & $\mathrm{NA}^{\mathrm{e}}$ & NA & 19 Oct & 4.15 & 12.4 \\
\hline & & & & & Yes & $31 \mathrm{Jul}$ & NA & NA & & 3.85 & 12.6 \\
\hline & AG2733 & Asgrow & 2.7 & 30 May & No & - & NA & NA & 19 Oct & 3.96 & 11.9 \\
\hline & & & & & Yes & $31 \mathrm{Jul}$ & NA & NA & & 4.05 & 11.9 \\
\hline & 39RY43 & Dynagrow & 3.9 & 30 May & No & - & NA & NA & 31 Oct & 3.92 & 9.93 \\
\hline & & & & & Yes & 2 Aug & NA & NA & & 3.81 & 10.0 \\
\hline
\end{tabular}

\footnotetext{
${ }^{a}$ Soybean maturity groups (MGs) are based on the day length required to begin the reproductive process; each whole-number MG increase adds approximately 10 days to the onset of flowering (Edwards and Purcell 2005).

${ }^{\mathrm{b}}$ Fungicide spray treatment $=292 \mathrm{ml} / \mathrm{ha}$ of $14.3 \%$ fluxapyroxad and $28.6 \%$ pyraclostrobin (Priaxor; BASF Inc.) applied at pod set (reproductive stage 3).

${ }^{\mathrm{c}}$ Dashes indicate the control treatment where no fungicides were sprayed.

${ }^{\mathrm{d}}$ Reproductive stage at the time of foliar endophyte sampling performed in 2015 and 2016: R5 = green pod, beginning seed; R6 = green pod, full seed; and R7 = yellow pod (Fehr and Caviness 1977).

e NA = not applicable, since only seeds were collected in 2017.
} 
for endophyte isolation. Stems cut just below the fifth node from the top of each plant and the associated nonsymptomatic leaves were placed on ice and processed within $6 \mathrm{~h}$ of collection. To process, 2-cm-long stem segments centered on the fifth node, and 2- $\mathrm{cm}^{2}$ leaf pieces from the base of the center trifoliate leaflet with the main vein centered were excised using a sterile blade. Samples were surface sterilized for $5 \mathrm{~min}$ in $8.25 \%$ sodium hypochlorite and $30 \mathrm{~s}$ in $70 \%$ ethanol, rinsed twice in sterile distilled water, and dried in a laminar flow hood on sterile paper towels. To verify the effectiveness of surface sterilization by bleach (Clorox), leaf and stem pieces were imprinted on plates of green bean agar (GBA) (411 g/liter of rinsed pureed cut Green Giant green beans; General Mills, Minneapolis, $\mathrm{MN}$ ) and $1.5 \%$ agar (Difco, Detroit, MI) prior to transfer to a second plate for endophyte isolation. Pieces on the imprinted plates showing external fungal growth after 7 to 30 days were eliminated from the study; the disinfection was considered successful when no fungal growth was observed (Parsa et al. 2016). Isolates associated with leaf and stem samples showing surface growth from preculture imprinting (22 of 192 samples in 2015 and 18 of 240 samples in 2016) were eliminated from the study. Surfaceborne isolates were identified as Penicillium sp., Aspergillus sp., and Cladosporium sp. based on colony and conidia morphology.

GBA was selected as the medium for primary isolation based on preliminary studies that showed that soybean leaf endophyte mycelia were more easily differentiated based on color, texture, and growth pattern than other media (data not shown). Cultures were incubated under ambient room temperature $\left(20\right.$ to $\left.25^{\circ} \mathrm{C}\right)$ and a light/dark regime. At 3 and 6 days, hyphal tips of newly emerged mycelia were transferred to antibiotic-amended one-third-strength potato dextrose agar (PDA) (BD, Franklin Lakes, NJ) in 2015 and 2\% water agar with a postautoclave addition of 40 drops of $50 \%$ lactic acid in 2016. Primary isolation plates were checked weekly for 3 months and new mycelial growth was subcultured. The colony color and texture of each primary isolate was described and recorded for each leaf or stem piece. Each isolate was assigned a number based on field, fungicide treatment, plant part, plant number, and colony from that primary isolation. A total of 708 and 1,083 isolates were detected on leaf and stem pieces in 2015 and 2016. Data from primary isolates made on GBA were used to estimate the incidence of species per stem or leaf piece. Every purified isolate was photographed and grouped into morphotype based on colony growth rate, texture, and color on acidified PDA (Fig. 1). Purified isolates totaled 505 in 2015 and 753 in 2016, comprising $70 \%$ of the total isolates detected from primary growth on GBA. Within these morphotype groups, each isolate was microscopically examined for delineating characteristics, including spores, appressoria, and fructifications, using an Olympus CHBS microscope with an eye piece micrometer; 20 measurements of these structures per isolate (when present) were recorded. Preliminary identifications to genus were based on Roy et al. (2001). Two- week-old pure cultures $(n=1,258)$ on PDA were placed in $15 \%$ glycerol and stored at $-80^{\circ} \mathrm{C}$.

DNA extraction, amplification, and sequencing. Representative isolates for molecular characterization (195 isolates in 2015 and 189 in 2016) were selected to include every fungal morphology. All sterile cultures and unique fungal morphologies were included; three to five isolates of commonly found fungal morphologies (Fig. 1) were chosen from each field, plant part, and fungicide treatment combination. Template DNA for PCR was extracted from representative cultures by scraping mycelia with a sterile pipette tip and transferring the mycelia into $50 \mu \mathrm{l}$ of PrepMan Ultra Sample Reagent (Applied Biosystems, Foster City, CA) following the manufacturer's instructions and was then stored at $-20^{\circ} \mathrm{C}$ until used. The internal transcribed spacer (ITS) region of the nuclear ribosomal DNA operon was amplified using the universal fungal primer pair ITS1 and ITS4 (White et al. 1990). DNA extraction, PCR reactions, purifications, and sequencing of products were performed as described in Batzer et al. (2005). The closest type material match for 16 species was putatively identified using the nBLAST tool. To verify the BLAST results, all generated sequences were manually aligned with downloaded sequences of well-documented strains or type cultures, when available, using BioEdit (Hall 1999). Alignments of each putative species did not differ by more than three base pairs. Fifteen sequences of representative isolates (as previously described in this paragraph) were deposited in GenBank (MG182675 to MG182675) and 373 additional sequences were subsequently deposited in GenBank as a population study SUB50478 and included accession numbers MK408985 to MK409358 (Table 3). Estimates of the number of endophyte operational taxonomic units (OTUs) isolated from each field sample were based on morphology and associated ITS sequences and grouped to genus.

Seed endophyte assay. The remaining lower portions and the entirety of sampled plants, in 2016 and 2017, respectively, were collected from the outer rows of each plot within 2 days after grain harvest of the center rows, as previously described (Table 1). Collected plants were stored in paper bags in the laboratory until seeds were manually removed from their pods within 4 weeks after harvest. A total of 1,440 seeds ( 6 fields $\times 4$ subplots $\times 3$ plants $\times$ 10 seeds $\times 2$ fungicide treatments) were assessed over 2 years (Table 1). Seeds were surface sterilized and rinsed as previously described. Single seeds were placed on 5-cm-diameter Petri plates of GBA and incubated as previously described. Seed germination was recorded at 2 weeks and fungal growth was identified to genus based on colony and conidia morphology over a period of 3 months.

Statistical analyses. The difference in the foliar endophyte community composition between fungicide-treated and no-spray control fields was evaluated using a multivariate abundance statistical model (mvabund: Statistical Methods for Analyzing Multivariate

Table 2. Number of plant samples, number of fungal isolates per sample, and genus richness of leaf and stem samples for each field and fungicide treatment

\begin{tabular}{|c|c|c|c|c|c|c|c|c|}
\hline \multirow[b]{2}{*}{ Year } & \multirow[b]{2}{*}{ Cultivar } & \multirow{2}{*}{$\begin{array}{l}\text { Fungicide } \\
\text { treatment }^{\mathrm{a}}\end{array}$} & \multicolumn{3}{|c|}{ Leaf } & \multicolumn{3}{|c|}{ Stem } \\
\hline & & & Samples $(n)^{\mathbf{b}}$ & Isolates/leaf $(n)$ & Richness $^{c}$ & Samples $(n)$ & Isolates/stem (n) & Richness \\
\hline \multirow[t]{6}{*}{2015} & AG2431 & No & 17 & 5.3 & 5 & 11 & 5.0 & 6 \\
\hline & & Yes & 11 & 5.3 & 6 & 10 & 4.1 & 6 \\
\hline & $31 \mathrm{RY} 45$ & No & 20 & 3.8 & 6 & 12 & 3.5 & 7 \\
\hline & & Yes & 19 & 3.3 & 4 & 12 & 3.6 & 5 \\
\hline & AG3334 & No & 16 & 6.3 & 5 & 11 & 2.4 & 5 \\
\hline & & Yes & 19 & 2.8 & 6 & 12 & 4.3 & 6 \\
\hline \multirow[t]{6}{*}{2016} & AG2035 & No & 20 & 5.3 & 7 & 20 & 3.7 & 7 \\
\hline & & Yes & 20 & 5.0 & 6 & 20 & 3.8 & 7 \\
\hline & NKS24K2 & No & 16 & 4.4 & 6 & 17 & 4.1 & 6 \\
\hline & & Yes & 20 & 5.9 & 7 & 18 & 3.4 & 6 \\
\hline & 39RY42 & No & 18 & 5.8 & 7 & 17 & 5.0 & 6 \\
\hline & & Yes & 18 & 7.2 & 6 & 18 & 3.4 & 4 \\
\hline
\end{tabular}

\footnotetext{
${ }^{a}$ Fungicide spray $=292 \mathrm{ml} / \mathrm{ha}$ of $14.3 \%$ fluxapyroxad and $28.6 \%$ pyraclostrobin at pod set (reproductive stage 3 ).

b Although 20 plants were collected, samples showing inadequate surface sterilization were eliminated from the study.

c Overall number of genera.
} 
Abundance Data, R package version 3.13.1, https://cran.r-project. org/web/packages/mvabund/index.html) (Wang et al. 2018). Preliminary analysis indicated genus composition differences between leaves and stems, so plant part (stems and leaves) was analyzed separately. For each plant part data set, the numbers of isolates from each of the six predominant genera were counted for each plant, field, and treatment. Fields were treated as blocks and the count per genus was modeled with a negative binomial distribution for overdispersed count data. $P$ values were obtained by resampling residuals.

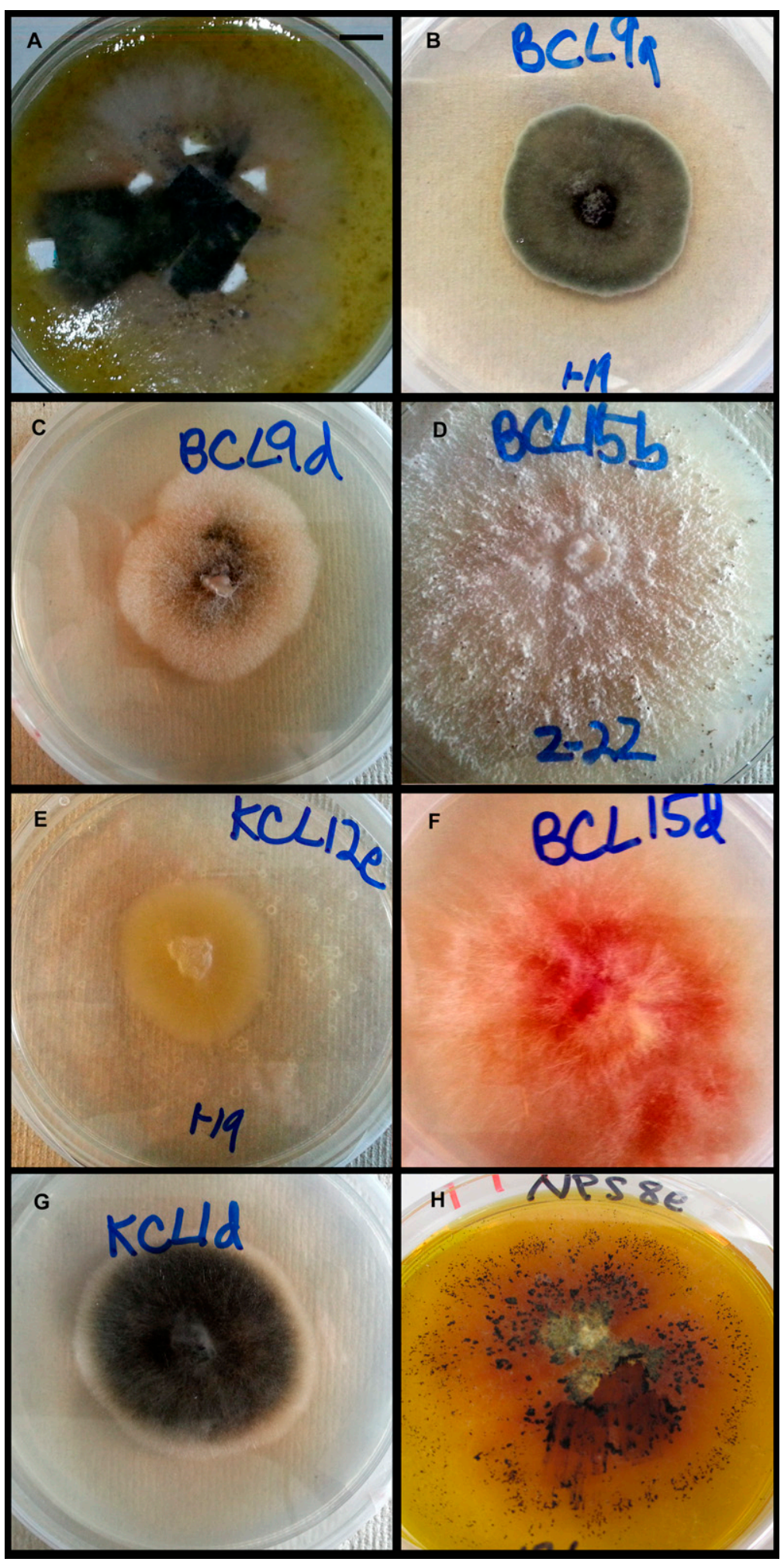

Fig. 1. Primary isolations were observed every 3 days and new mycelial growth was subcultured to acidified potato dextrose agar. A, A 2-week-old leaf isolation on green bean agar is shown. Growth was categorized based on colony color and texture and each morphology was recorded for each leaf and stem piece. Frequently observed morphologies were grouped as follows: B, olive, felty, thick (genus Alternaria); C, pale pink or white with submerged dark centers, velvety, even margins (genus Colletotrichum); D, white, felty, dense (genus Diaporthe); E, white to pale yellow, smooth, margins feathered (genus Fusarium); F, deep pink and white, floccose (genus Fusarium); G, black, narrow white edge, floccose (genus Nigrospora); and $\mathbf{H}$, golden, with black specks, thin, diffusible yellow pigment (genus Didymella-like). 
Mean numbers of isolates of each leaf and stem sample and endophyte OTU genus richness were determined. Isolates per sample were compared among plant part, fungicide treatment, and field using an analysis of variance with plant part and fungicide as fixed effects and field and year as random effects (Table 2).

The effect of fungicide treatment $(n=2)$, year $(n=2)$, and cultivar $(n=6)$ on the percentage of seed infection was compared using an analysis of variance in which cultivar and fungicide treatment were fixed effects and replicated subplot $(n=4)$ and year $(n=2)$ were random effects. Analysis was conducted separately for each genus where percent infection (30 seeds) was compared. A Fisher protected least significant difference test $(P \leq 0.05)$ was also used to compare Diaporthe infection fungicide differences among individual cultivars and among the four MGs (2.0, 2.4, 2.7, and 3.9) with SAS version 9.3 software (SAS, Cary, NC). To determine the strength of the association of fungicide spray impact to MG ( $x$-axis) of the field cultivar on Diaporthe seed infection ( $y$-axis), a Pearson correlation was conducted using Microsoft Excel.

\section{Results}

Field conditions. Across the 3-year study, fungicide-sprayed treatment fields showed a small $(1.8 \%)$ but significant increase $(P=0.0154)$ in seed moisture at the time of harvest compared with the no-spray fields, suggesting that the fungicide spray delayed senescence (Table 1). The mean yield for all soybean plots was $4.7 \mathrm{t} / \mathrm{ha}$ (Table 1) and was not affected by fungicide treatment $(P=0.4143)$. Symptoms of foliar diseases including brown spot, frogeye leaf spot, Cercospora leaf blight, and sudden death syndrome were observed in the fields at green pod full seed stage (R6); their causal organisms were not detected from any endophyte samples in this study. Reproductive stages at the dates of foliar collections ranged from R5 to R7; short-season MGs were closer to senescence (Table 1). Total rainfall from planting to harvest dates was $67.7,61.2$, and $25.34 \mathrm{~cm}$ in 2015, 2016, and 2017 respectively, differing greatly from the 47.9-cm 30-year average in Ames, Iowa. Soil temperatures showed a comparatively cool growing season in 2015, and warmer growing seasons in 2016 and 2017, although all years were warmer than the 30-year average.

Numbers of foliar endophyte isolates. Paired comparisons showed that more isolates $(P=0.0111)$ were obtained from leaves (5.0 isolates/leaf) than stems (3.8 isolates/stem) (Table 2). The mean number of isolates per plant (4.4) did not differ among year $(P=0.1545)$, fungicide treatment $(P=0.6150)$, or field $(P=$ 0.2358 ). A total of 708 and 1,083 isolates were examined and commonly occurring morphologies were grouped (Fig. 1). Purified isolates $(n=1,258)$ were subsequently identified to genus or species based on colony morphology and microscopic characters (Roy et al. 2001).

Diversity. Most of the isolates were known pathogens on soybean or other plant hosts (Table 3). Based on ITS sequence alignments, a total of 17 species were isolated, with 14 species in 2015 and 15 species in 2016 belonging to 10 genera (Table 3 ). Based on the morphology of primary isolates, the most frequently isolated species across year and field were Alternaria destruens (696 isolates) and Colletotrichum cliviae (365 isolates). Alignment of ITS sequences among isolates showed no more than three base pair differences within $A$. destruens and Colletotrichum cliviae. The species frequency of every isolate within the genera Diaporthe, Fusarium, and Nigrospora could not be determined based on primary isolate morphology. Consequently, each isolate was placed into an OTU at the genus level

Table 3. Closest matches to soybean endophyte putative species, GenBank accessions, closest BLAST search results to type material (when possible), operational taxonomic unit (OTU) genus group, and lifestyle preferences

\begin{tabular}{|c|c|c|c|c|c|c|}
\hline \multirow{2}{*}{$\begin{array}{l}\text { Soybean endophyte } \\
\text { closest match }\end{array}$} & \multirow{2}{*}{$\begin{array}{l}\text { Soybean } \\
\text { endophyte } \\
\text { DMPC }^{\text {a }}\end{array}$} & \multirow[b]{2}{*}{ GenBank accession ${ }^{\mathbf{b}}$} & \multicolumn{2}{|c|}{ BLAST match sequence } & \multirow[b]{2}{*}{ OTU genus } & \multirow[b]{2}{*}{ Lifestyle preference ${ }^{c}$} \\
\hline & & & Accession & Base pair identity $^{\mathbf{b}}$ & & \\
\hline Alternaria destruens & KCL7c & MG182675, MK408985-MK409129 & NR_137143 & $550 / 550$ & Alternaria & Saprobic, endophytic, and pathogenic \\
\hline $\begin{array}{l}\text { Colletotrichum } \\
\text { cliviae }\end{array}$ & $\mathrm{KCS} 3 \mathrm{a}$ & MG182676, MK409134-MK409200 & NR_137097 & $496 / 499$ & Colletotrichum & $\begin{array}{l}\text { Saprobic, endophytic, and pathogenic } \\
\text { (anthracnose) }\end{array}$ \\
\hline Diaporthe aspalathi & LPS11a & MK409201-MK409216 & KX769840 & $580 / 601$ & Diaporthe & $\begin{array}{l}\text { Endophytic and pathogenic } \\
\text { (southern stem canker) }\end{array}$ \\
\hline Diaporthe actinidiae & KPL4d & MG182679, MK409227-MK409233 & KC145886 & $549 / 550$ & Diaporthe & $\begin{array}{l}\text { Endophytic and pathogenic } \\
\text { (kiwi stem rot) }\end{array}$ \\
\hline Diaporthe caulivora & KCL14d & MG182677, MK409227-MK409233 & NR_111845 & $566 / 571$ & Diaporthe & $\begin{array}{l}\text { Endophytic and pathogenic } \\
\text { (northern stem canker) }\end{array}$ \\
\hline Diaporthe longicolla & KPS7a & MG182678, MK409217-MK409226 & NR_144924 & $549 / 551$ & Diaporthe & $\begin{array}{l}\text { Endophytic and pathogenic (soybean } \\
\text { seed decay and stem disease) }\end{array}$ \\
\hline Diaporthe novem & LPS16b1 & MK409234-MK409239 & MH864503 & $576 / 592$ & Diaporthe & $\begin{array}{l}\text { Endophytic and pathogenic } \\
\text { (soybean seed decay) }\end{array}$ \\
\hline $\begin{array}{l}\text { Fusarium boothii } \\
\text { (F. graminearum } \\
\text { complex })\end{array}$ & KPS5c & MG182680, MK409269-MK409305 & NR_121203 & $536 / 536$ & Fusarium & Saprobic, endophytic, and pathogenic \\
\hline $\begin{array}{l}\text { F. equiseti } \\
\quad \text { (F. graminearum } \\
\text { complex) }\end{array}$ & $\mathrm{KCS7e}$ & MG182681, MK409306-MK409313 & NR_121457 & $532 / 537$ & Fusarium & Saprobic, endophytic, and pathogenic \\
\hline $\begin{array}{l}\text { F. keratoplasticum } \\
(\text { F. solani group })\end{array}$ & KPS8b & MG182682, MK409317-MK409328 & NR_130690 & $524 / 533$ & Fusarium & Saprobic, endophytic, and pathogenic \\
\hline Nigrospora oryzae & KPS11b & MG182683, MK409336-MK409341 & EU529994 & $533 / 533$ & Nigrospora & $\begin{array}{l}\text { Saprobic, endophytic, and pathogenic } \\
\text { (leaf spot) }\end{array}$ \\
\hline N. sphaerica & KPS10c & MG182684, MK409329-MK409335 & KJ767121 & $539 / 539$ & Nigrospora & $\begin{array}{l}\text { Saprobic, endophytic, and pathogenic } \\
\text { (leaf spot) }\end{array}$ \\
\hline Didymella rosae & NPL2E & MG182685, MK409240-MK409267 & NR_136125 & $544 / 567$ & Didymella-like & Pathogenic (tan spot) \\
\hline $\begin{array}{l}\text { Epicoccum } \\
\text { sorghinum }\end{array}$ & $\mathrm{KCS} 2 \mathrm{c}$ & MG182686 & KY454467 & $539 / 539$ & $\mathrm{NA}^{\mathrm{d}}$ & Pathogenic (grain mold) \\
\hline $\begin{array}{l}\text { Coniothyrium } \\
\text { multiporum }\end{array}$ & KPL2b & MG182687 & NR_111617 & $422 / 450$ & NA & Endophyte \\
\hline $\begin{array}{l}\text { Bipolaris } \\
\quad \text { subramanianni }\end{array}$ & CUL2c & MG182688, MK409130-MK409133 & NR_147496 & $611 / 619$ & NA & Pathogenic (leaf spot) \\
\hline $\begin{array}{l}\text { Plectosphaerella } \\
\text { populi }\end{array}$ & LU85B & MG182689 & NR_138002 & $547 / 582$ & NA & Pathogenic (root and collar rots) \\
\hline
\end{tabular}

a DMPC = Daren Mueller Personal Collection.

b Isolates in bold were used to perform BLAST searches. Additional sequences were deposited as a population study SUB50478 and included accession numbers MK408985 to MK409358.

${ }^{\mathrm{c}}$ Lifestyle preference assignments were based on source information of the closest BLAST accession and on Hartman et al. (2015).

$\mathrm{d} \mathrm{NA}=$ not assigned. 
based on morphological characteristics of each isolate and ITS sequences of representative isolates.

Endophyte community structure. A multivariate test was conducted separately for leaf and stem plant parts. "Community" was defined as the percentage of each fungal endophyte genus across the isolates sampled from each field $(n=6)$ and fungicide treatment. Since the analysis was within field, the differences between years or reproductive stages were ignored. When considering all six genera, fungicide treatment impacted the leaf $(P=0.020)$ and the stem $(P=0.007)$ endophyte community. Further paired analysis within fields testing whether the fungicide spray treatment and the nospray control have the same community showed that genus Diaporthe was increased in the fungicide spray treatment for both stems and leaves and genus Alternaria was decreased in the fungicide spray treatment (Fig. 2).

Seed endophyte assay. Genera Alternaria (14\%) and Diaporthe $(12.5 \%)$ were the most commonly isolated endophytes from surface-sterilized seeds collected after harvest in 2016 and 2017. Alternaria infection rarely killed the seed (2\%), whereas nearly all Diaporthe-infected seeds failed to germinate (98\%) at 2 weeks. Colletotrichum, Fusarium, and Didymella-like endophytes were detected in low numbers $(0.3,1.2$, and $1.3 \%$, respectively) and were not affected by fungicide treatment; seed death was not observed in seed infected with these fungi, although necrosis was often observed on developing roots. The percentage of Diaporthe seed infection was greatly impacted by cultivar and fungicide treatment $(P<$ $0.0001)$ but these factors did not affect other fungal genera $(P>$ 0.05). Further analysis on the percentage of Diaporthe seed infection detected an interaction of cultivar and fungicide treatment $(P=$ 0.0008), which suggested that the effect of fungicide was not constant across soybean cultivar. When we grouped cultivar into MGs (Table 1), we found that the treatment effect (fungicide spray) was greater for shorter-season MGs 2.0 and $2.4(P=0.0021$ and $P=$ 0.0488), but fungicide spray did not impact Diaporthe infection for longer-season MGs 2.7 and $3.9(P=0.4065$ and $P=0.0998)$ (Fig. 3). A Pearson correlation of MG $(x)$ versus the difference between the Diaporthe infection percentage of fungicide spray and no-spray control treatment $(y)$ showed a negative relationship $(r=-0.5303)$.

\section{Discussion}

This is the first report that a foliar fungicide spray increased the incidence and predominance of endophytic Diaporthe infection in stems, leaves, and seed. Diaporthe species are widely recognized endophytes in many plant species (Gomes et al. 2013; Huang et al. 2015; Murali et al. 2006; Rajamani et al. 2018; Suryanarayanan et al. 2018) and are also the cause of soybean diseases including stem canker, pod and seed decay, and Phomopsis seed decay (Wrather et al. 2003). The Diaporthe soybean disease community has an extended latent phase, and presumably these organisms become pathogenic when plants become stressed or senesce (Sinclair 1991). Our ITS sequences suggested that several Diaporthe species may be soybean endophytes. Additional sequences, including beta tubulin, are required to delineate Diaporthe species (Gomes et al. 2013; Huang et al. 2015) and this research is being conducted.

Conversely, we showed that a foliar fungicide decreased Alternaria endophytes in leaves and did not affect Colletotrichum endophytes. Genera Alternaria and Colletotrichum were the most frequently isolated foliar endophytes in our study and were commonly found in Argentina and Brazil soybeans (Larran et al. 2002). Colletotrichum endophytes are abundant in

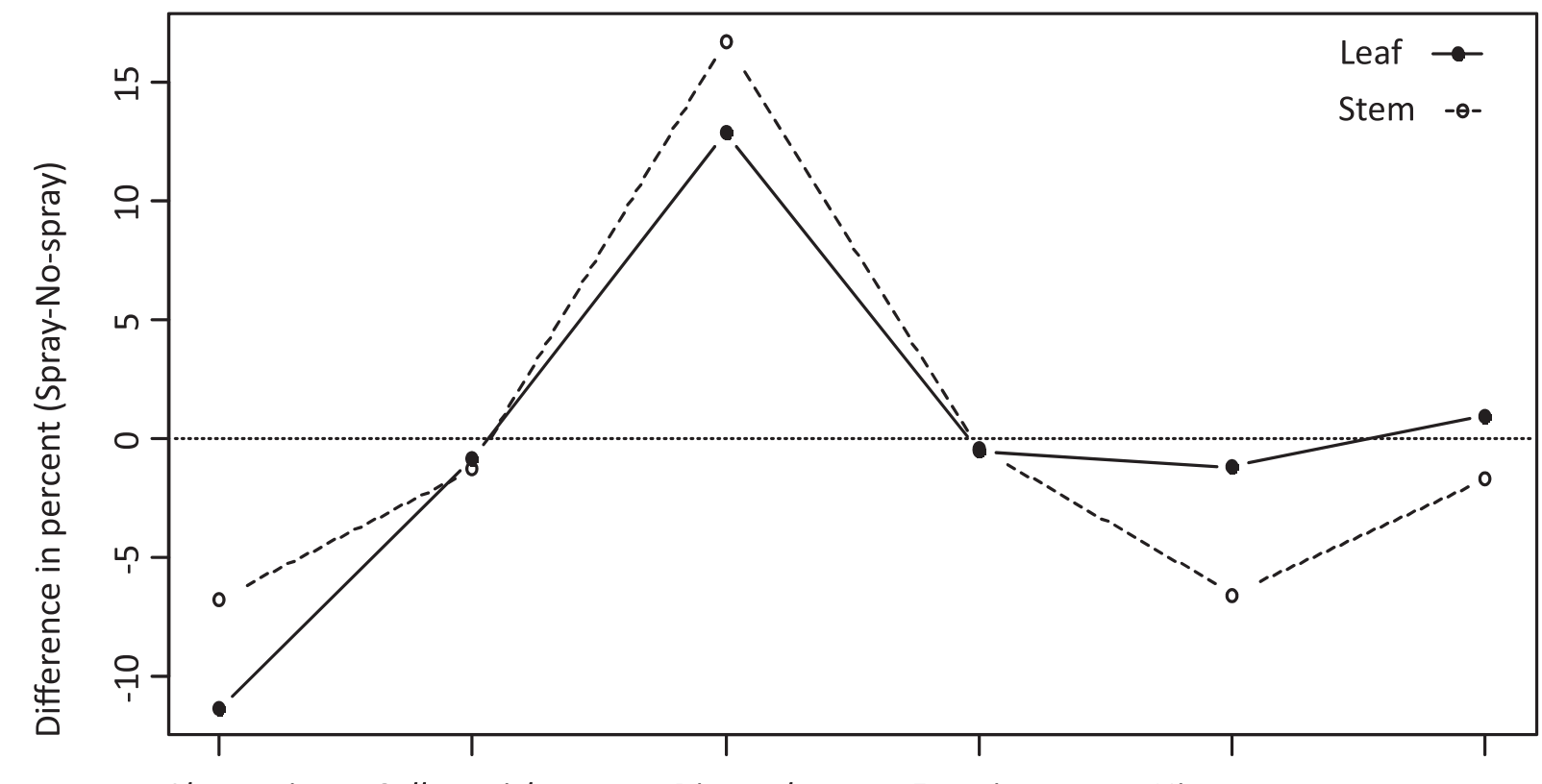

\begin{tabular}{|c|c|c|c|c|c|c|c|c|c|c|c|c|}
\hline \multirow{2}{*}{$\begin{array}{l}\text { Genus } \\
\text { Plant } \\
\text { part }\end{array}$} & \multicolumn{2}{|c|}{ Alternaria } & \multicolumn{2}{|c|}{ Colletotrichum } & \multicolumn{2}{|c|}{ Diaporthe } & \multicolumn{2}{|c|}{ Fusarium } & \multicolumn{2}{|c|}{ Nigrospora } & \multicolumn{2}{|c|}{ Didymella-like } \\
\hline & Leaf & Stem & Leaf & Stem & Leaf & Stem & Leaf & Stem & Leaf & Stem & Leaf & Stem \\
\hline \multicolumn{13}{|c|}{ Spray-No spray (percent) } \\
\hline Mean & -11.33 & -6.78 & -0.81 & -1.26 & 12.86 & 16.74 & -0.52 & -0.43 & -1.17 & -6.56 & 0.98 & -1.70 \\
\hline SE & 4.31 & 3.59 & 5.87 & 3.19 & 3.50 & 4.85 & 1.03 & 2.37 & 2.61 & 5.70 & 2.14 & 1.44 \\
\hline \multicolumn{13}{|c|}{ Test for Difference $=0$} \\
\hline T-stat & -2.63 & -1.893 & -0.14 & -0.394 & 3.674 & 3.45 & -0.51 & -0.18 & -0.45 & -1.15 & 0.46 & -1.18 \\
\hline P-value & 0.0468 & 0.1172 & 0.8956 & 0.7095 & 0.0144 & 0.0182 & 0.6339 & 0.8635 & 0.6707 & 0.3018 & 0.6672 & 0.2905 \\
\hline
\end{tabular}

Fig. 2. Community analysis showing the percent differences in the predominant endophyte community during pod fill (reproductive stage 5 ) in leaves and stems between a fungicide spray at early pod set (reproductive stage 3 ) and no-spray control treatment for six fields. The table values below each genus on the $x$-axis show the plotted mean percent differences, the standard error, and the statistical results (T-statistic and $P$ value) of testing for treatment differences for each plant part. 
legumes (Gonzaga et al. 2015) and other hosts (Photita et al. 2005; Suryanarayanan et al. 2018). Many of the same genera we detected were also reported as soybean endophytes in Minnesota, Brazil, or Argentina (da Costa Stuart et al. 2018; Impullitti and Malvick 2013; Larran et al. 2002; Pimentel et al. 2006). These fungi, in addition to Fusarium and Nigrospora fungi, have been routinely isolated as endophytes; all four of these fungi are known as weak parasites (Larran et al. 2002; Pan and May 2009; Roy et al. 2001; Suryanarayanan et al. 2018) and as plant decomposers (Dighton 2016). Fusarium sp. endophytes have shown potential as beneficial endophytes against nematodes ( Vu et al. 2006). In a separate ongoing study, we are using isolates collected in this study to determine the virulence of soybean endophytes on germinating seeds.

Our findings suggest that many commonly found endophytes can be vertically transmitted through the seed and may explain why we found similar endophyte composition in our 2015 and 2016 fields, which were a few kilometers apart, and why these genera are reported in most soybean producing locations in the western hemisphere. Seed transmission by genus Alternaria has been reported (Hodgson et al. 2014).

We have shown that a fungicide application at pod set had lasting effects on the endophytic community of late-season plants through harvest, as was previously found with common and broad bean (Prior et al. 2017). We also found that the increase in Diaporthe seed infection mostly occurred for early maturing cultivars, but less for later-maturing soybeans. This suggests that the QoI fungicideinduced maturity delay, known as the "greening affect" (Balba 2007), extended the window of opportunity for vertical transmission of Diaporthe seed during periods of warm temperatures. Increased seed rot is associated with short-season cultivars, in which the maturation period is more often accompanied by higher temperatures and humidity than for long season cultivars (Balducchi and McGee 1987), as we observed. Our results support the finding of Wrather et al. (2004) that the QoI fungicide azoxystrobin increased the incidence of D. longicolla seed infection. In contrast, Berkland (2011) reported that an application of the QoI fungicide pyraclostrobin at growth stage pod set reduced $D$. longicolla seed infection by $1.9 \%$. The slight but significant increase of seed moisture at harvest in the fungicide-sprayed plots across all cultivars may be related to the higher incidence of seed rot and fungal growth.

Another factor that may account for the impact of fungicide treatment on the foliar endophytic community and the increased Diaporthe seed infection is QoI resistance. The single mode of action of QoI fungicides makes these compounds vulnerable to selective pressure by fungi that have mutations that allows them to service in the presence of QoI fungicides (Miles et al. 2012). Our culture collection is a valuable resource for assessing fungicide sensitivity of endophytes.

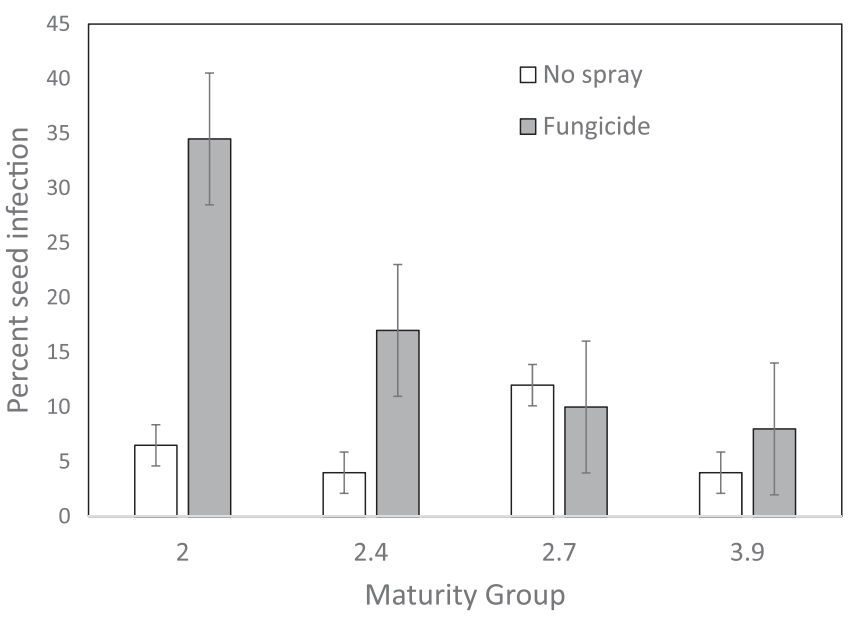

Fig. 3. Percentage of Diaporthe sp. seed infection from soybean cultivars with differing maturity groups that were sprayed with a fungicide at early pod set (reproductive stage 3 ) versus no spray. Error bars represent the standard deviation of each subplot cultivar combination within each maturity group.
The relatively low diversity of endophytes detected in the aboveground tissues ( 17 species) in this study was surprising considering the hyperdiverse fungal endophyte community associated with tropical and boreal trees and herbaceous plants (Arnold 2007; Rodriguez et al. 2009). Possible reasons for this reduced diversity may be related to the agronomic conditions of the soybean crops that were not grown in their native location; rather they were grown in rotated annual cropping systems in temperate latitudes, with strict weed and insect control, in fields that were tilled to reduce crop residue after harvest, and from commercially produced seed. da Costa Stuart et al. (2018) reported that diversity, richness, and evenness decreased in soybeans grown with conventional practices compared with organically grown soybeans. In that study, a 30\% reduction of genera was attributed to pesticide use and the precipitous reduction of fungi recovered as the season progressed. Although the culture-dependent methods that we used in this study provided a similar OTU richness reported in other soybean foliar endophyte surveys (Impullitti and Malvick 2013; Larran et al. 2002; Pimentel et al. 2006), direct sequencing would certainly yield a much higher fungal richness than culture-dependent methods (Bakker et al. 2017; Bonito et al. 2016; de Souza Leite et al. 2013). Furthermore, our imprint method prior to culturing reduced the diversity we obtained but assured us that those isolates were truly endophytic, which could not be certain using PCR because DNA from dead fungi on surfaced sterilized tissue can be amplified (Siddique et al. 2017).

Knowledge of easily culturable species present in asymptomatic plants and our extensive culture collection will allow us to examine the impact of these prevalent endophytes on crop hosts and the microbial community, as well as to determine the influence of environment on these fungi. In conclusion, soybean producers may want to consider that the application of a QoI fungicide in the absence of disease pressure might adversely affect seed quality.

\section{Acknowledgments}

We thank Stith Wiggs for managing the field plots and Kate Sandage, Allegra Selzer, and Margaret McGrath for assistance with PCR and culturing. We also thank Philip Dixon for statistical advice.

\section{Literature Cited}

American Society of Agricultural and Biological Engineers. 2017. ASEA S352.2 APR1988 (R2017): Moisture Measurement-Unground Grain and Seeds. American Society of Agricultural and Biological Engineers, St. Joseph, MI.

Arnold, A. E. 2007. Understanding the diversity of foliar endophytic fungi: Progress, challenges, and frontiers. Fungal Biol. Rev. 21:51-66.

Bakker, M. G., Moorman, T. B., Kaspar, T. C., and Manter, D. K. 2017. Isolation of cultivation resistant oomycetes, first detected as amplicon sequences, from roots of herbicide-terminated winter rye. Phytobiomes 1:24-35.

Balba, H. 2007. Review of strobilurin fungicide chemicals. J. Environ. Sci Health Part B. 42:441-451.

Balducchi, A. J., and McGee, D. C. 1987. Environmental factors influencing infection of soybean seeds by Phomopsis and Diaporthe species during seed maturation. Plant Dis. 71:209-212.

Batzer, J. C., Gleason, M. L., Harrington, T. C., and Tiffany, L. H. 2005. Expansion of the sooty blotch and flyspeck complex on apples based on analysis of ribosomal DNA gene sequences and morphology. Mycologia 97: 1268-1286.

Berkland, T.D., 2011. Soybean seed production: Decisions and their relationship to seed quality. Master's thesis (paper 12030), Iowa State University, Ames.

Bonito, G., Hameed, K., Ventura, R., Krishnan, J., Schadt, C. W., and Vilgalys, R. 2016. Isolating a functionally relevant guild of fungi from the root microbiome of Populus. Fungal Ecol. 22:35-42.

Borges, W. D. S., and Pupo, M. T. 2006. Novel anthraquinone derivatives produced by Phoma sorghina, an endophyte found in association with the medicinal plant Tithonia diversifolia (Asteraceae). J. Braz. Chem. Soc. 17:929-934.

Bradley, K. W., and Sweets, L. E. 2008. Influence of glyphosate and fungicide coapplications on weed control, spray penetration, soybean response, and yield in glyphosate-resistant soybean. Agron. J. 100:1360-1365.

Christian, N., Sullivan, C., Visser, N. D., and Clay, K. 2016. Plant host and geographic location drive endophyte community composition in the face of perturbation. Microb. Ecol. 72:621-632.

da Costa Stuart, A. K., Stuart, R. M., and Pimentel, I. C. 2018. Effect of agrochemicals on endophytic fungi community associated with crops of organic and conventional soybean (Glycine max L. Merril). Agric. Nat. Resour. (Bangk.) 52:388-392.

de Lima Fávaro, L. C, de Souza Sebastianes, F. L., and Araújo, W. L. 2012. Epicoccum nigrum P16, a sugarcane endophyte, produces antifungal compounds and induces root growth. PLoS One 7:e36826. 
de Souza Leite, T, Cnossen-Fassoni, A., Pereira, O. L., Mizubuti, E. S. G., de Araújo, E. F., and de Queiroz, M. V. 2013. Novel and highly diverse fungal endophytes in soybean revealed by the consortium of two different techniques. J. Microbiol. 51:56-69.

Dighton, J. 2016. Fungi in Ecosystem Processes, Vol. 31. CRC Press, Boca Raton, FL.

Edwards, J. T., and Purcell, L. C. 2005. Soybean yield and biomass responses to increasing plant population among diverse maturity groups. Crop Sci. 45: 1770-1777.

Fehr, W. H., and Caviness, C. E. 1977. Stages of soybean development. Spec. Rep. Coop. Ext. Serv. Agric. Home Econ. Exp. Stn., Iowa State Univ. 80:1-12.

Gao, Y., Zhao, J. T., Zu, Y. G., Fu, Y. J., Wang, W., Luo, M., and Efferth, T. 2011. Characterization of five fungal endophytes producing Cajaninstilbene acid isolated from pigeon pea [Cajanus cajan (L.) Millsp.]. PLoS One 6:e27589.

Gomes, R. R., Glienke, C., Videira, S. I. R., Lombard, L., Groenewald, J. Z., and Crous, P. W. 2013. Diaporthe: A genus of endophytic, saprobic and plant pathogenic fungi. Persoonia 31:1-41.

Gonzaga, L. L., Costa, L. E. O., Santos, T. T., Araújo, E. F., and Queiroz, M. V. 2015. Endophytic fungi from the genus Colletotrichum are abundant in the Phaseolus vulgaris and have high genetic diversity. J. Appl. Microbiol. 118: 485-496.

Hall, T. A. 1999. BioEdit: A user-friendly biological sequence alignment editor and analysis program for Windows 95/98/NT. Nucleic Acids Symposium Series 41:95-98.

Hamayun, M., Khan, S. A., Ahmad, N., Tang, D. S., Kang, S. M., Na, C. I., Sohn, E. Y., Hwang, Y. H., Shin, D. H., Lee, B. H., and Kim, J. G. 2009. Cladosporium sphaerospermum as a new plant growth-promoting endophyte from the roots of Glycine max L. Merr. World J. Microbiol. Biotechnol. 25: 627-632.

Hartman, G. L., Rupe, J. C., Sikora, E. J., Domier, L. L., Davis, J. A., and Steffey, K. L., eds. 2015. Compendium of Soybean Diseases and Pests. American Phytopathological Society, St. Paul, MN.

Hodgson, S., Cates, C., Hodgson, J., Morley, N. J., Sutton, B. C. and Gange, A. C. 2014. Vertical transmission of fungal endophytes is widespread in forbs. Ecol. Evol. 4:1199-1208.

Hoffman, M. T., and Arnold, A. E. 2008. Geographic locality and host identity shape fungal endophyte communities in cupressaceous trees. Mycol. Res. 112:331-344.

Huang, F., Udayanga, D., Wang, X., Hou, X., Mei, X., Fu, Y., Hyde, K. D., and Li, H. 2015. Endophytic Diaporthe associated with citrus: A phylogenetic reassessment with seven new species from China. Fungal Biol. 119:331-347.

Impullitti, A. E., and Malvick, D. K. 2013. Fungal endophyte diversity in soybean. J. Appl. Microbiol. 114:1500-1506.

Kandel, Y. R., Mueller, D. S., Hart, H. E., Bestor, N. R. C., Bradley, C. A., Ames, K. A., Giesler, L. J., and Wise, K. A. 2016. Analyses of yield and economic response from foliar fungicide and insecticide applications to soybean in the North Central United States. Plant Health Prog. 17:232-238.

Karlsson, I., Friberg, H., Steinberg, C., and Persson, P. 2014. Fungicide effects on fungal community composition in the wheat phyllosphere. PLoS One 9: e111786.

Khan, A. L., Hamayun, M., Ahmad, N., Hussain, J., Kang, S. M., Kim, Y. H., Adnan, M., Tang, D. S., Waqas, M., Radhakrishnan, R., and Hwang, Y. H. 2011. Salinity stress resistance offered by endophytic fungal interaction between Penicillium minioluteum LHL09 and Glycine max L. J. Microbiol. Biotechnol. 21:893-902.

Kuklinsky-Sobral, J., Araujo, W. L., Mendes, R., Pizzirani-Kleiner, A. A., and Azevedo, J. L. 2005. Isolation and characterization of endophytic bacteria from soybean (Glycine max) grown in soil treated with glyphosate herbicide. Plant Soil 273:91-99.

Larran, S., Rollán, C., Bruno Angeles, H., Alippi, H. E. and Urrutia, M. I. 2002. Nota corta: Endophytic fungi in healthy soybean leaves. Investigación agraria. Producción y protección vegetales 17:173-178.

Miles, L. A., Miles, T. D., Kirk, W. W., and Schilder, A. M. C. 2012. Strobilurin (QoI) resistance in populations of Erysiphe necator on grapes in Michigan. Plant Dis. 96:1621-1628.

Mueller, D. S., ed. 2013. Fungicides for Field Crops. American Phytopathological Society, St. Paul, MN.

Murali, T. S., Suryanarayanan, T. S., and Geeta, R. 2006. Endophytic Phomopsis species: Host range and implications for diversity estimates. Can. J. Microbiol. 52:673-680.

Oono, R., Lefèvre, E., Simha, A., and Lutzoni, F. 2015. A comparison of the community diversity of foliar fungal endophytes between seedling and adult loblolly pines (Pinus taeda). Fungal Biol. 119:917-928.

Pan, J. J., and May, G. 2009. Fungal-fungal associations affect the assembly of endophyte communities in maize (Zea mays). Microb. Ecol. 58: 668-678.
Parsa, S., García-Lemos, A. M., Castillo, K., Ortiz, V., López-Lavalle, L. A. B. Braun, J., and Vega, F. E. 2016. Fungal endophytes in germinated seeds of the common bean, Phaseolus vulgaris. Fungal Biol. 120:783-790.

Photita, W., Taylor, P. W. J., Ford, R., Hyde, K. D., and Lumyong, S. 2005. Morphological and molecular characterization of Colletotrichum species from herbaceous plants in Thailand. Fungal Divers. 18:117-133.

Pimentel, I. C., Glienke-Blanco, C., Gabardo, J., Stuart, R. M., and Azevedo, J. L. 2006. Identification and colonization of endophytic fungi from soybean (Glycine max (L.) Merrill) under different environmental conditions. Braz. Arch. Biol. Technol. 49:705-711.

Prior, R., Mittelbach, M., and Begerow, D. 2017. Impact of three different fungicides on fungal epi-and endophytic communities of common bean (Phaseolus vulgaris) and broad bean (Vicia faba). J. Environ. Sci. Health Part B 52:376-386.

Rajamani, T., Suryanarayanan, T. S., Murali, T. S., and Thirunavukkarasu, N 2018. Distribution and diversity of foliar endophytic fungi in the mangroves of Andaman Islands, India. Fungal Ecol. 36:109-116.

Redman, R. S., Dunigan, D. D., and Rodriguez, R. J. 2001. Fungal symbiosis from mutualism to parasitism: Who controls the outcome, host or invader? New Phytol. 151:705-716.

Redman, R. S., Sheehan, K. B., Stout, R. G., Rodriguez, R. J., and Henson, J. M 2002. Thermotolerance generated by plant/fungal symbiosis. Science 298: 1581.

Rodriguez, R. J., White, J. F., Arnold, A. E., and Redman, R. S. 2009. Fungal endophytes: Diversity and functional roles. New Phytol. 182:314-330.

Roy, K. W., Baird, R. E., and Abney, T. S. 2001. A review of soybean (Glycine max) seed, pod, and flower mycofloras in North America, with methods and a key for identification of selected fungi. Mycopathologia 150:15-27.

Schulz, B., and Boyle, C. 2005. The endophytic continuum. Mycol. Res. 109: 661-686.

Siddique, A. B., Khokon, A. M., and Unterseher, M. 2017. What do we learn from cultures in the omics age? High-throughput sequencing and cultivation of leafinhabiting endophytes from beech (Fagus sylvatica L.) revealed complementary community composition but similar correlations with local habitat conditions. MycoKeys 20:1-16.

Sinclair, J. B. 1991. Latent infection of soybean plants and seeds by fungi. Plant Dis. 75:220-224.

Suryanarayanan, T. S., Devarajan, P. T., Girivasan, K. P., Govindarajulu, M. B., Kumaresan, V., Murali, T. S., Rajamani, T., Thirunavukkarasu, N., and Venkatesan, G. 2018. The host range of multi-host endophytic fungi. Curr. Sci. 115:1963-1969.

Suryanarayanan, T. S., Thirunavukkarasu, N., Govindarajulu, M. B., and Gopalan, V. 2012. Fungal endophytes: An untapped source of biocatalysts. Fung. Div. 54:19-30

Swoboda, C., and Pedersen, P. 2009. Effect of fungicide on soybean growth and yield. Agron. J. 101:352-356.

Tadych, M., Bergen, M., Dugan, F. M., and White, J. F. 2007. Evaluation of the potential role of water in spread of conidia of the Neotyphodium endophyte of Poa ampla. Mycol. Res. 111:466-472.

U'Ren, J. M., Lutzoni, F., Miadlikowska, J., Laetsch, A. D., and Arnold, A. E. 2012. Host and geographic structure of endophytic and endolichenic fungi at a continental scale. Am. J. Bot. 99:898-914.

Vu, T., Hauschild, R., and Sikora, R. 2006. Fusarium oxysporum endophytes induced systemic resistance against Radopholus similis on banana. Nematology 8:847-852.

Wang, Y., Naumann, U., Eddelbuettel, D., and Warton, D. 2018. mvabund: Statistical Methods for Analysing Multivariate Abundance Data. R package version 3.13.1. https://cran.r-project.org/web/packages/mvabund/index.html

White, J. F., Tadych, M., Torres, M. S., Bergen, M. S., Irizarry, I., Chen, Q., and Zambell, C. 2016. Endophytic microbes, evolution and diversification of. Pages 505-510 in: Encyclopedia of Evolutionary Biology. R. M. Kliman, ed. Vol. 1. Academic Press, Oxford, UK.

White, T. J., Bruns, T., Lee, J., and Taylor, J. 1990. Amplification and direct sequencing of fungal ribosomal RNA genes for phylogenetics. Pages 315-322 in: PCR Protocols: A Guide to Methods and Applications. M. A Innis, D. H. Gelfand, J. J. Sninsky, and T. J. White, eds. Academic Press, San Diego, CA.

Wise, K., and Mueller, D. 2011. Are fungicides no longer just for fungi? An analysis of foliar fungicide use in corn. APSnet Features. doi: 10.1094/ APSnetFeature-2011-0531

Wrather, J. A., Shannon, J. G., Stevens, W. E., Sleper, D. A., and Arelli, A. P. 2004. Soybean cultivar and foliar fungicide effects on Phomopsis sp. seed infection. Plant Dis. 88:721-723.

Wrather, J. A., Sleper, D. A., Stevens, W. E., Shannon, J. G., and Wilson, R. F. 2003. Planting date and cultivar effects on soybean yield, seed quality, and Phomopsis sp. seed infection. Plant Dis. 87:529-532. 